\title{
The concept of sustainable regional development - institutional aspects, policies and prospects
}

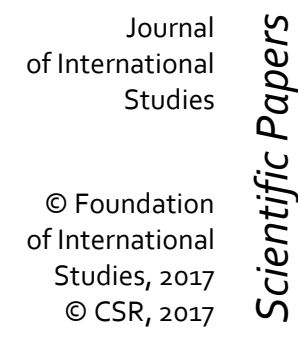

\author{
Radislav Jovovic \\ Mediteranean University, Podgorica \\ Montenegro \\ radejovovic@t-com.me
}

Mimo Draskovic

Maritime Faculty of Kotor, University of Montenegro

Montenegro

rookie@t-com.me

Milica Delibasic

International University of Travnik

Bosnia and Herzegovina

23.mildel@gmail.com

Miroslav Jovovic

International University of Travnik

Bosnia and Herzegovina

miroslav.jovovid@cbcg.me

Abstract. Growing market globalization, increasing global competition, more complex products results in application of new technologies, methods and business processes - due to the abovementioned tendencies novel supply chain strategies (Lean, Agile and Leagile Supply Chains) are established. In this study these supply chain concepts are being described and compared. Virtual enterprise is a temporary alliance of enterprises that come together to share their skills, core competencies, costs and resources in order to better respond to rapidly changing market environment and dynamic customer demands. Economic and social benefits and effects of virtual enterprises for customers and production companies and service providers are also described. Optimization software has been developed for optimal formation of virtual enterprise networks and is also introduced in this study. The aim of this software application is to define virtual enterprise as the optimal combination of supply chain members.

Keywords: sustainable development, regional sustainable development, integration.

JEL Classification: R58

Received: January, 2017 1st Revision: March, 2017

Accepted: March, 2017

DOI: 


\section{INTRODUCTION}

Over the past four decades, the World have become increasingly aware of environmental problems. The environmental issues since 1972 (when the first international conference on the environment problems was hold), has been only growing worldwide. The world institutions (like the United Nations Conference on Environment and Development (UNCED)) concentrate their attention on major global issues mostly including depletion of the Earth's protective ozone layer, destruction of tropical and old-growth forests and wetlands, species extinction, and the steady buildup of carbon dioxide and other "greenhouse" gases causing global warming and climate change. However, over four decade of efforts taken on overcoming the environmental problems very fable progress has been achieved. The UNEP reports offer evidence that the global environmental problems identified at the UNCED gathering back in 1992 have continued or worsened. With the exception of ozone depletion, an area in which major reduction in emissions has been achieved by international agreement, In addition, UNEP points to exposure to toxic chemicals and hazardous wastes, nitrogen pollution in freshwater and oceans, water contamination and declining groundwater supplies, forest and freshwater ecosystem damage, overexploitation of major ocean fisheries, urban air pollution and wastes. Underlying all these problems is the demography issue, including population growth which adds more than 70 million people a year. The world population, which had passed 7 billion by the year 2015, is expected to grow to around 9 billion by 2030 .

Under urgent pressure of environmental destruction, scientists and politicians have begun to work on finding solutions for sustainable development. The main research questions in this regard are: How to prevent irreversible damage to the planetary systems that supports life? How to avoid high environmental price caused by non-responsible behavior of businesses? How to find a balance between economic development and environment operating the "environment-friendly" development concept? The notion of sustainable development encompasses both economic and environmental goals with the use of sustainable techniques for better agricultural production, energy use, natural resource management, and industrial production (Straková, 2015; Dočekalová et al., 2015; Rutkauskas et a., 2014). Today we have enough evidence to state that these techniques have significant potential, but have yet to be widely adopted. A sustainable global economy also implies limits on population growth and material consumption. The question of economic activity sustainability has already become the major issue, and will be even more important in the coming decades.

Sustainable development has been defined in a variety of ways, but in practice it has three dimensions - economic, environmental and social ones. The word "sustainability" has become a global buzzword as a potential solution for many international, regional, and local problems facing society today: overpopulation, diseases, political conflicts, infrastructure deterioration, pollution, and unlimited urban expansion under limited resources' availability. The United Nations World Commission on Environment and Development (WECD, 1987) coined a definition of sustainable development, which is probably the most well-known in all of sustainability literature: "development that meets the needs of the present without compromising the ability of future generations to meet their own needs".

\section{THEORETICAL BACKGROUNDS OF SUSTAINABLE DEVELOPMENT OF REGIONS}

The concept of sustainable development is based on three dimensions mentioned above. Regions' development is usually defined as the integral community development (social, economic, environmental and healthcare, technological, cultural and recreational ) on a particular territory. Region's development must 
be based on their optimal expansion constituents (social, natural and economic development aspects) aimed at certain life's level maintenance and quality improvement through the mentioned constituents. Regional development encompasses not only traditional policy on a concrete territory, but also socioeconomic process organized in the specific political and cultural context (Atkinson, 1996; Bourdeu, 1999; Spangenberg, 2002). Regional development in today's context is at a critical juncture, with multiple crises (financial, food and energy) forcing us to re-assess the economic paradigm of our time and to evaluate how to better address the unfulfilled promises that we are currently leaving to future generations in the areas of employment, social progress, quality of life and respect for nature. While there is no doubt about the importance of integration of the pillars of sustainable development onto the regional level, implementation of this concept has proved challenging in practice. In fact, integration of the environmental, economic, and social dimensions of sustainable development on the regional level implies the implementation of complimentary and coordinated actions in different areas which results in economic growth that is also supposed to achieve social objectives, without endangerment the rare resources of the planet. Effective integration of these three dimensions (pillars) requires the implementation of a set of focused and specific actions, which are complimentary and fit within an overarching sustainable development framework.

Three classes of issues discussed above are arranged as vertices of a triangle - depicted as Munasinghe's triangle (figure 1) to imply that achieving sustainability involves finding solutions which balance the importance and impacts of each of these three categories (after Munasinghe, in Pearce, 1999). This provides a good classification system for sustainability properties, and highlights issues such as social and political impacts which have often been omitted from consideration in traditional design processes, or otherwise, overshadowed by variables such as time, cost, and quality. Another model (Mensah and Castro, 2004, p. 5) shows the interaction among the three components with a middle 'zone of sustainability' which recognizes the interdependence of biological, economic and social systems (Spies, 2003). In business, this notion of three integrated aspects is sometimes called the 'Triple Bottom Line' - increasing profits, improving the planet and improving the lives of people.

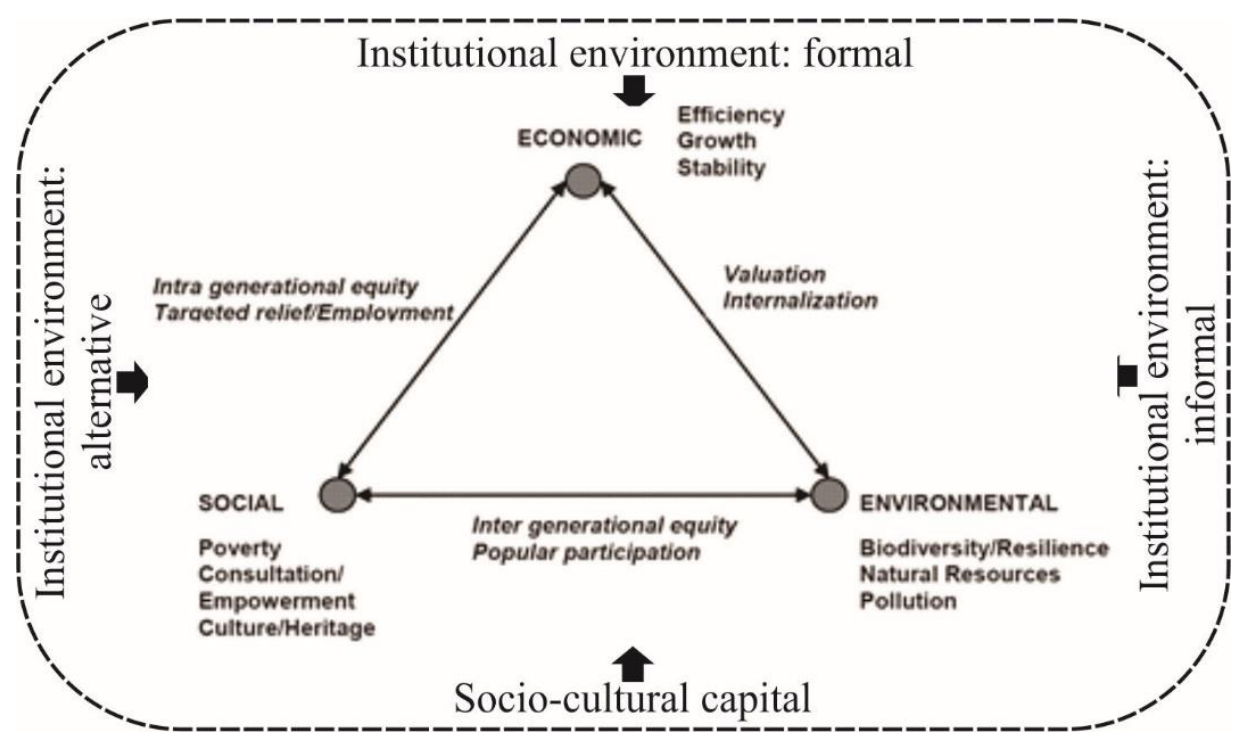

Figure 1. Munasinghe's Approach to Sustainable Development

Source: Adapted to Pearce, 1999. 
Therefore, sustainability of region is the process suggested to improve the quality of human life within the limitations of the global environment. It involves solutions for improving human welfare that does not result in degrading the environment or impinging on the wellbeing of other people. This concept are involved in sustainable measures: understanding the interconnections among economy, society, and environment; living within certain limits of the earths' capacity to maintain life; and maintaining a fair distribution of resources and opportunity for this generation and the next. The above concept was redefined as the community as whole system, made up of three concentric circles: the economy is found within society, and both the economy and society exist within the environment. Sustainability indicators are set to measure the extent to which these boundaries are respected.

A different framework was proposed by the economist H. Daly (1990) who rearranged sustainability into a triangular setup of the 3E's - Environment, Equity and Economy (figure 2). At the bottom of the triangle is the Environment or the 'Ultimate Means' which represents natural resources as a precondition for decent human life. The Economy (which includes technology, politics and ethics) is on the next rung, is not independent but serves as a vehicle for achieving ultimate ends. At the top is Equity, or the 'Ultimate End' which refers to the wellbeing of the human being. According to Daly, the economy therefore succeeds to the extent that it conserves and restores ultimate means (the environment), and enables the achievement of ultimate ends (equity).

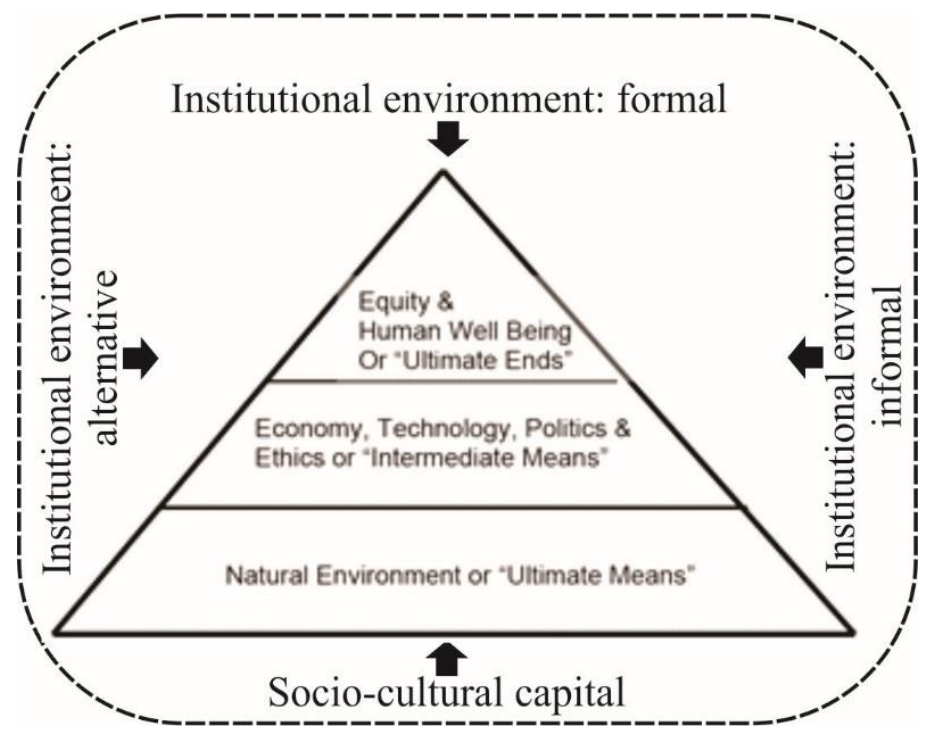

Figure 2. Daly's Triangle of Equity, Economy and Environment

Source: Adapted to: www.sustainablesonoma.org/keyconcepts/dalystriangle.html

Sustainability is also a political term. It has been used in a certain historical situation in response to specific problems. Its political utility is mainly composed of novelty and flexibility, in its capacity to gather consensus and to shift perceptions and values at the same time. These attributes do not correspond to scientific efforts for precise meanings (Thierstein \& Walser, 2000). Today, the concept of sustainability is a hub for many different approaches. It is used for various policy issues, development processes and planning strategies at regional level. There are several important features related to the term "sustainability" (see Thierstein \& Walser, 1997): the first is that sustainability requires awareness of the interconnection of social, ecological and economic problems; Secondly, all concepts of sustainability are based on different needs 
within the region and therefore require a lot of knowledge of how to deal with different interests; As a third feature, implementation of sustainability concepts at the regional level should bring together local needs formulated in 'Local Agenda 21' - and demands for co-operation created over problems above the local level.

Regional sustainability is defined as "the continuous support of human quality of life within a region's ecological carrying capacity" (Wackernagel \& Yount, 1998; Streimikiene, 2014). Sustainable development is understood in the category of economic development assuming the availability of certain natural resources in the region. However, economic development should remain at a level not exceeding the environmental capacity of the region (Malik \& Ciesielska, 2011; Streimikiene, et al., 2016). There are two approaches to sustainable development in the region, the product oriented and the process oriented. The first approach is the value that the region provides to its users, while the second approach focuses on the fundamental processes occurring in the region. The process approach is closely linked with the process of drafting a development strategy of the region and the wider concept of regional planning.

This concept fills a subordinate role towards regional guidelines. The main issue is how to achieve the broader goals, using existing processes and resources. In practice, achieving these goals with the support of existing processes is not always feasible. The effective combination of these two approaches is a major challenge for the governing bodies of the region. Beyond using variables of the region, decision-making processes in managing the volatility of the region require the inclusion of the external environment. The most important external variables affecting the functioning of the region are: new technologies or the competitiveness of the regions (Kondratiuk-Nierodzińska, 2016, 451-471). These external factors often have a direct impact on regional strategy formulation. Local and regional authorities have the task of maintaining a balance between the two leading forces within the region, namely the income maximization for the region, its community and local businesses, and the efficient use of available resources in accordance with the principles of sustainable development and reducing the impact of negative externalities on the region's functioning (Ibid., p. 170). Sustainability within the region is realized through integration within orderliness of sustainability: economical, eco-space, socio-institutional and ethical (Ibid, p. 171). Integration within the region is implemented through strategies and development programs. Development plans are operational dimension of regional development strategy (Stimson, Stough, \& Roberts, 2006, p. 85).

\section{THE CONCEPT OF SUSTAINABLE REGIONAL DEVELOPMENT IN EUROPE UNION}

The concept of sustainable regional development (SRD) in Europe Union refers to the integration of sustainable development principles into regional development practice. Accordingly, SRD encompasses all activities and instruments that promote sustainable development within regional economic initiatives. This focus is justified firstly by the important role of regions as intermediaries between national and local levels, and secondly by the growing consensus that sustainability is an essential criterion within future regional development. In addition to matching policy trends at EU and national levels, each of which is moving towards much more integrated forms of operation, SRD aims to act as a catalyst in raising awareness amongst regional development professionals. It illustrates that there is no longer scope to concentrate only on economic growth, and this broader perspective encompasses activities ranging from establishing new forms of partnership to exploring innovative planning and integration methodologies. Although it represents a relatively new field, substantial knowledge and expertise in SRD already exist, and it has advanced sufficiently in theory and practice to become recognized as a specialist field with an emerging body of literature, as well as associated intellectual dilemmas and problems of realization (Clement, Hansen 
\& Bradley, 2003). The key documents attempting to rationalize SRD have recently been augmented by an EU Thematic Evaluation on the Contribution of the Structural Funds to Sustainable Development (Commission of the European Communities, 2001; 2002). This evaluation had three main objectives: To develop methods, indicators and approaches for the evaluation of sustainable regional development; To identify ways throughout the delivery system for the Structural Funds to generate better projects promoting sustainable development; To identify the main policy trade-offs being made in regional development policies either explicitly or implicitly.

The synthesis report provides tools and methodologies to assist regions, Member States and the EU in assessing the sustainability of development plans and to enhance the sustainability of the Structural Funds programs in the 2000-2006 period. It is also intended to act as guidance in the preparation of Structural Funds policies beyond 2006, with particular relevance for programs in the new Member States (the former Candidate Countries). In its approach, the study modifies the three pillars (economy, society and environment) conceptualization of sustainable development into four types of capital that sustain wellbeing: manufactured (man-made), natural, human and social capital. The potential for sustainable or unsustainable development lies in the trade-offs occurring between the different forms of capital, when an increase in one prompts a corresponding increase or decrease in another. Thereafter, when proposing tools to assess regional sustainability, the report develops the concept of regional development pathways and designs a sustainability assessment matrix, specifying criteria against which to evaluate policies, programs or projects.

Finally, a 'project pipeline checklist' provides questions for program managers and monitoring committees designed to generate projects that contribute more effectively to SD. In parallel with the EU activity, the theoretical and practical development of SRD has been supported by a series of multidisciplinary conferences and international workshops. This momentum has included comparative research into instruments for SRD, the formation of ENSURE, the European Network for Sustainable Urban and Regional Development Research, and the launch of REGIONET, an EU Thematic Network project aimed at providing an interdisciplinary approach to support the implementation of sustainable regional development in Europe. A key element of this exploratory process has been the identification of differentiated experience between countries and regions, offering considerable scope and need for researchers and practitioners to learn from each other.

In what is known as the Daly Triangle, Daly (1973 in Meadows, 1998) refers to the different forms of capital to describe various inputs that contribute to the ultimate objective of increasing human well-being. This recognizes that each form of capital contributes to human well-being in unique ways. In contrast, the understanding that all forms of capital are substitutable (the weak sustainability approach, explained further on) leads to the widespread acceptance that trade-offs are necessary and inevitable. For instance, if the services provided by the natural environment to the society and to the economy can be substituted by manufactured capital, then there is no need to conserve natural capital-it can be considered non-essential. There is an assumption that the decline in other natural assets can be managed and that the needs of future generations will be met as long as there is no decline in economic output. Such an approach is referred to as weak sustainability, whereby natural and other assets are declining while that of manufactured capital grows. In such a perspective, natural capital and the services provided by nature can be substituted by manufactured capital and are valuable only as long as they contribute to economic growth and welfare.

It is increasingly evident, however, that below certain stock levels (critical thresholds), particular components of capital are non-substitutable. Neoclassical economic theory has traditionally held that as long as there is no decline in economic growth, substitutes for exhaustible resources can always be found. 
Thus, there are no resource constraints to economic growth. As human beings slowly but eventually discovered, even if resource limits are relative and can be overcome, the capacity of the planetary ecosystem to absorb the output of economic growth is limited. There are absolute limits to the planet's carrying capacity, as evidenced through planetary changes in terms of global warming, climate change and biodiversity loss. It is in such a context, in which substitution between economic, manufactured or classic capital and natural resources or natural capital is recognized as unsustainable in the long term. This strong sustainability approach provides a more effective basis for policy formulation for integration that seeks synergies and integration of the three dimensions of sustainable development in policy outcomes (UN, 2015,).

\section{CHANGING PERSPECTIVE: FROM GLOBAL TO REGIONAL APPROACH}

Sustainable development started off small, but soon became an issue at the global policy level. Lafferty (2004) dubs the UNCED process leading towards the Rio Declaration and Agenda 21 (A21) in 1992 as an "outside-in program" meaning that it transpired largely outside the realm of normal domestic politics. The number of actors involved in designing Agenda 21 was small and very professional, draft documents were known to only a limited number of people and goals were formulated in a highly abstract manner. However, A21 requested the involvement of all sorts of major groups, who were at the time not even aware of their responsibilities. The first task of governments was then to translate the results of the Rio-conference to their citizens and major gro-ups, with the ultimate idea that sustain able development would be implemented at the subnational level (cf. UN, 1992; 2002). The sub-national level which is defined in this thesis as the regional level is thought to have, in terms of geographic scale, an optimal size for successfully implementing sustainable development: small enough to be concrete and of direct interest to residents and large enough to possess critical mass for collective action and creative solutions (UN, 1992; Zilahy \& Huisingh, 2009). The UN repeatedly affirm the importance of local and regional authorities in achieving sustainable development. A region should be seen in this thesis as an area smaller than a nation that has an identity demarcated by boundaries (an administrative entity) or identified by relatively homogeneous economic, social, or landscape characteristics. In this sense, a region can cross borders (e.g., the Euro region MeuseRhine includes parts of Belgian, Dutch and German provinces and is an area with a shared history and similar economic interests). Graymore et al. (2008) contend that the regional level provides the greatest opportunity for local governments to work together with their constituent communities toward sustainable development.

Although implementation of sustainable development policy is expected to happen at the regional level, this is not the case. At EU level, interlinkages between the national and regional policy level are not well developed and national strategies for sustainable development are "rather weak policies" which have only a "limited capacity to guide sustainable development governance" (Research Institute for Managing Sustainability). What we see worldwide since the Rio Conference in 1992 is a fragmented approach towards sustainable development, no significant changes in consumption and production patterns, a lack of mutually coherent policies and approaches in the areas of finance, trade, investment, technology and sustainable development, and a lack of resources for implementing Agenda 21 (UN, 2001; UN 2017; UN, 2016). The EU's 2009 Presidency report reviewing the EU Sustainable Development Strategy (SDS) also expresses concern about the ongoing unsustainable trends and the limited results in curbing them. This is confirmed by the European Council and a request is made for reinforcing "governance, including implementation, monitoring and follow-up mechanisms". Also Eurostat mentions in its 2009 monitoring report of the EU SDS that "little progress seems to have been made since the 2007 Monitoring Report, confirming that more efforts are 
necessary in the European Union to get on the pathway to sustainable development". A question we should ask is, what makes realizing sustainable development so difficult?

\subsection{The regional development strategy}

A shared vision of region is the first step in developing strategy of sustainable development. It articulates region's opportunities. This Vision supports the aim of the PfG "to build a shared and better future for all". The RDS coordinates the PfG and the associated Investment Strategy, first of policies with a spatial dimension and providing the strategic spatial policy context for decisions by both central and local Government. That helps the Executive to tackle structural regional disparities and promote equality of opportunity for all. It will provide a series of high level strategic objectives, associated policies and indicators with environmental, economic, and societal themes (Kogut-Jaworska, 2015). The overarching aim is to meet wider economic and social needs, while limiting environmental impact and realizing reductions in harmful emissions.

The main aims are: balanced regional growth, support strong, sustainable growths for the benefit haring wealth across the region, support towns, villages and rural communities to maximize their potential, promote development which improves the health and well-being of communities, take advantage of the economic, social and environmental opportunities which are open to it. Improved health and wellbeing, improve connectivity to enhance the movement of people, goods, and information between places, protect and enhance the environment for its own sake, and facilitate adaptation to climate change. It is recognized that climate change is one of the most serious problems facing the world. We are all contributors to global warming and need to play our part to reduce and offset our impact on the environment. We need to reduce harmful greenhouse gas emissions to help reduce the threat of climate change and promote sustainable construction, consumption and production. We should aim to prevent waste and deal with it in line with the revised Waste Framework Directive. Everyone should contribute to reducing the Region's carbon footprint. The aims of the Strategy support the Executives principles towards achieving balanced subregional growth (Table 1).

Table 1

The aims of the Strategy Support the Executives Principles Towards Achieving Balanced Subregional Growth

\begin{tabular}{|c|c|c|c|c|}
\hline \multicolumn{2}{|c|}{ Peace } & \multicolumn{2}{|c|}{ Fairness } & \multirow[t]{2}{*}{ g } \\
\hline 仓 & 仓 & 仓 & 仓 & \\
\hline $\begin{array}{c}\text { Growing a } \\
\text { sustainable } \\
\text { economy and } \\
\text { investing in the } \\
\text { future }\end{array}$ & $\begin{array}{c}\text { Creating, } \\
\text { opportunities, } \\
\text { tacking } \\
\text { disadvantage and } \\
\text { improving health } \\
\text { and well-being }\end{array}$ & $\begin{array}{l}\text { Protecting our } \\
\text { people, the } \\
\text { environment and } \\
\text { creating safer } \\
\text { communities }\end{array}$ & $\begin{array}{l}\text { Building a strong } \\
\text { and shared } \\
\text { community }\end{array}$ & $\begin{array}{l}\text { Delivering high } \\
\text { quality and } \\
\text { efficient public } \\
\text { service }\end{array}$ \\
\hline
\end{tabular}

Source: RDS 2035, 2010, p. 20.

Implementation of the Vision and aims of the RDS requires a Spatial Framework to enable strategic choices to be made in relation to development and infrastructural investment. It will also assist private investment decisions. It provides a degree of continuity with the existing policy, but sets new guidelines and priorities to better achieve sustainable development in the interest of future generations. The person is put at the center. In realizing these guidelines it is essential an understanding of how different places are 
influenced by the range of services and functions required by individuals, their locations, how frequently they are used and by whom. This helps give a clearer understanding of the relationship between people and places - an appreciation of where people live, work and access services.

The Hierarchy of Settlements and Related Infrastructure Wheel (RDS 2035, 2010, p. 24) illustrates the range of public and private services needed to ensure citizens have access to the necessary economic, social and cultural opportunities, as well as the infrastructure required by businesses to build a competitive dynamic and innovative economy. These services include education, health, social transport and communication networks, environment, commercial and justice. The wheel outlines the patterns of service provision that are likely to be appropriate at different spatial levels including neighborhoods, smaller towns, regional towns (or groups of towns) and cities or at a regional level. The model recognizes the strong relationship between settlement size and the levels of service that can be supported. The wheel provides a forward perspective, providing some under-standing of the level of facilities and services anticipated at different spatial levels rather than necessarily reflecting the stock of services that are currently available in villages, towns, cities or regionally. The outer level of the wheel illustrates not only the infrastructure that would be appropriate for principal cities but also those of regional significance.

This approach also recognizes that: a) settlements often provide either a greater or lesser range of services than the core population may dictate. It is not appropriate therefore to consider 'urban' population alone in classifying service settlements within any district - the population of rural hinterlands can also support services in urban centers; b) service centers tend to be hierarchical, with a large number of centers providing a smaller range of services, and a smaller number of centers providing a wider range. Each class of settlement provides services lower down in the hierarchy; and c) access to services and facilities is important. Creating a critical mass to support a level of services raises challenges for service providers in meeting the needs of spatially dispersed populations.

\section{INSTITUTIONAL ASPECTS OF SUSTAINABLE REGIONAL DEVELOPMENT}

The six subsystems correspond to potentials that must be sustainably maintained. Although other classifications are possible, this identification of subsystems is not arbitrary. These subsystems are all essential parts of the anthroposphere, i.e., the sphere that is affected by and affects human society. The major relationships between the six subsystems are shown in Fig. 3.

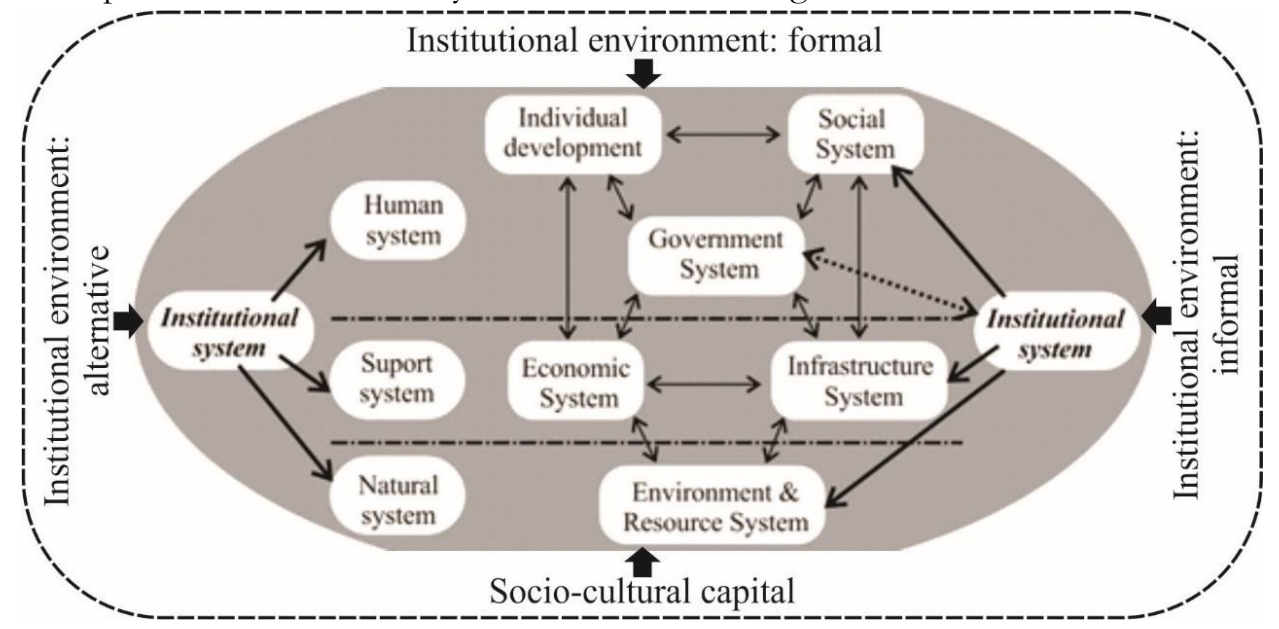

Figure 3. The six major systems of the anthroposphere and their major relationships Source: Adapted to Bosel, 1999, p. 18. 
Each of these subsystems can be viewed as representing a certain type of potential that is vital to the development of the total system (Bosel, 1999, p. 18; Shuaibu \& Oladayo 2016, pp. 531-532). In this connection, the term potential denotes a stock or capital of a vital asset, which can grow or depreciate, and must be maintained in good state in order to contribute its share to the development of the total system. The above figure of $\mathrm{H}$. Bosel (Ibid) authors adjusted by institutional system, taking into account that it is important component of sustainable development, on the global level as well as on the local one. It is in line with approach of F. Langeweg, H. Hilderink and R. Maas (2000, p. 5), showed on fig. 4.

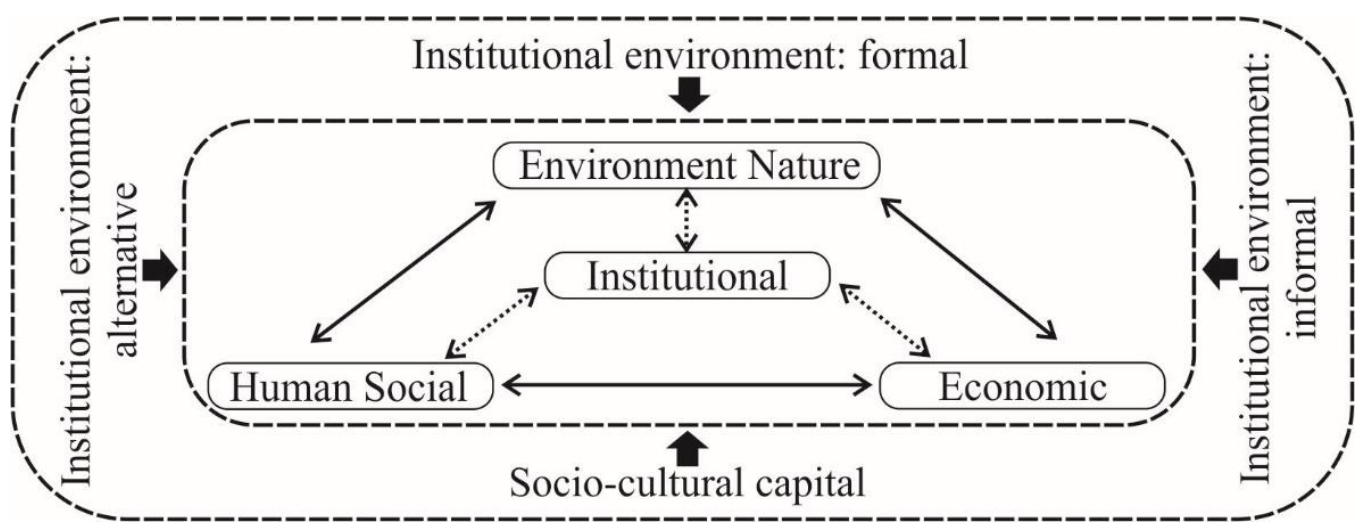

Figure 4. Characterization of sustainable development: the interaction between economic, environmental, human and institutional domains

Source: Adapted to Langeweg, Hilderink \& Maas, 2000, p. 5.

The CSD at its eleventh session (2003) adopted a new multi-year programs of work based on a twoyear cycle to 2017, alternating between review and policy sessions. At its thirteenth session (2005), the Commission reaffirmed both its mandate and its role as the high-level commission responsible for sustainable development within the UN system, and it addressed measures for voluntary monitoring, reporting and assessment at national and regional levels.

\section{CONCLUSION}

Under urgent pressure of environmental destruction, scientists and politicians have begun to work on finding solutions for sustainable development. Sustainable development has been defined a variety of ways, but in practice it has three dimensions economic, environmental and social. This concept has evolved in sustainable measures: living within certain limits of the earths' capacity to maintain life; understanding the interconnections among economy, society, and environment; and maintaining a fair distribution of resources and opportunity for this generation and the next.

The synthesis in this paper proposes tools to help how to achieve regional development pathways and how to design the framework as base for finding trade-offs between all dimensions of notion sustainable development. The overarching aim is to meet wider economic and social needs, while limiting environmental impact and realizing reductions in harmful emissions. The institutional component has been recognized as the most important for achieving trade-of between economic issues, and environmental ones. 


\section{REFERENCES}

Atkinson, A. (1996). Developing indicators of sustainable community: lessons from sustainable Seattle. Environmental Impact Assessment Review, 16(4-6), 337-350.

Bossel, H. (1999). Indicators for sustainable development: theory, method, applications (pp. 1-124). Winnipeg: International Institute for Sustainable Development. Retrieved http://publ.ext.zalf.de/web/lsa_ergebnisse_agstruk_indikatoren/pdfs $\% 5$ Cbalatonreport.pdf (accessed at 20 Dec 2016)

Bourdeau, L. (1999). Sustainable development and the future of construction: a comparison of visions from various countries. Building Research \& Information, 27(6), 354-366.

Clement, K., Hansen, M., \& Bradley, K. (2003). Sustainable regional development: Learning from Nordic experience. Nordregio.

Commission of the European Communities (2001). Promoting a European framework for Corporate Social Responsibility. Brussels.

Commission of the European Communities (2002). Corporate Social Responsibility: A business contribution to Sustainable Development. Brussels.

Dočekalová, M. P., Kocmanová, A., \& Koleňák, J. (2015). Determination of economic indicators in the context of corporate sustainability performance. Business: Theory and Practice/Verslas: Teorija ir Praktika, 16(1), 15-24.

Graymore, M. L., Sipe, N. G., \& Rickson, R. E. (2008). Regional sustainability: How useful are current tools of sustainability assessment at the regional scale?. Ecological economics, 67(3), 362-372.

Kogut-Jaworska, M. (2015). Identification of Smart Specialisations in Polish Regions in the Context of the EU's New Financial Perspective 2014-2020. Oeconomia Copernicana, 6(2), 23-36.

Kondratiuk-Nierodzińska, M. (2016). New Knowledge Generation Capabilities and Economic Performance of Polish Regions. Equilibrium. Quarterly Journal of Economics and Economic Policy, 11(3), 451-471.

Lafferty, W. M. (Ed.). (2006). Governance for sustainable development: The challenge of adapting form to function. Edward Elgar Publishing.

Langeweg, F., Hilderink, H., \& Maas, R. (2000). Urbanisation, industrialisation and sustainable development. RIVM report 402001015. Retrieved from: http://www.pbl.nl/sites/default/files/cms/publicaties/402001015.pdf (accessed at 29 Nov. 2016).)

Malik, K., \& Ciesielska, M. (2011). Sustainability within the region: the role of institutional governance. Economic and Environmental Studies, 11(2), 167-187.

Meadows, D. H. (1998). Indicators and information systems for sustainable development. Sustainability Institute, Hartland, Vermont.

Mensah, A. M., \& Castro, L. C. (2004). Sustainable resource use \& sustainable development: a contradiction. Center for Development Research, University of Bonn.

Munasinghe, M. (1993). Environmental economics and sustainable development (Vol. 3). World Bank Publications.

Pearce, A. R. (1999). The Science and Engineering of Sustainability: A Primer. Institute of Sustainable Technology and Development, Georgia Institute of Technology, Atlanta, GA. Retrieved from: http://maven.gtri.gatech.edu/sfi/resources/pdf/TR/TR018.PDF

Regional Development Strategy 2035 - Building a Better Future (2010). Department for Regional Development, Belfast.

Rodríguez, M. R., De Ruyck, J., Díaz, P. R., Verma, V. K., \& Bram, S. (2011). An LCA based indicator for evaluation of alternative energy routes. Applied Energy, 88(3), 630-635.

Rutkauskas, A. V., Raudeliuniene, J., \& Racinskaja, I. (2014). Integral Knowledge, Innovation and Technology Cluster Formation Nurturing the Universal Development Sustainability in the Context of Globalization. Economics \& Sociology, 7(4), 41.

Shuaibu, M. (2016). Determinants of Human Capital Development in Africa: A Panel Data Analysis. Oeconomia Copernicana, 7(4), 523-549.

Spangenberg, J. H. (2002). Environmental space and the prism of sustainability: frameworks for indicators measuring sustainable development. Ecological indicators, 2(3), 295-309. 
Spies, A. (2003). The sustainability of the pig and poultry industries in Santa Catarina, Brazil: a framework for change, Doctorate Thesis, University of Queensland, Brisbane, Australia.

Stimson, R. J., Stough, R. R., \& Roberts, B. H. (2006). Regional Economic Development: Analysis and Planning Strategy. Revised Edition, Springer, Berlin.

Straková, J. (2015). Sustainable value added as we do not know it. Business. Theory and Practice, 16(2), 168-173.

Streimikiene, D. (2014). Comparative assessment of environmental indicators of quality of life in Romania and Lithuania. Economics \& Sociology, 7(1), 11-21

Streimikiene, D., Strielkowski, W., Bilan, Y., \& Mikalauskas, I. (2016). Energy dependency and sustainable regional development in the Baltic States-a review. Geographica Pannonica, 20(2), 79-87.

Thierstein, A., \& Walser, M. (1997). Sustainable regional development the squaring of the circle or a gimmick? Entrepreneurship \& Regional Development, 9(2), 159-174.

Thierstein, A., \& Walser, M. (1999, August). Sustainable Regional Development: Interplay of topdown and bottomup approaches. In Conference Paper. St. Gallen. Retrieved from: http://www-sre.wuwien.ac.at/ersa/ersaconfs/ersa99/Papers/a139.pdf

UN (1992). Agenda 21. United Nations, New York.

UN (2002). Report of the World Summit on Sustainable Development. A/CONF.199/20 and A/CONF.199/20/corr.1, United Nations, New York.

UN (2007). Indicators of Sustainable Development: Guidelines and Methodologies. Third Edition, New York.

UN (2015). Integrating the three dimensions of sustainable development: A framework and tools. ECCAP, Bangkok, Thailand.

UN (2016). Trade development policies and the post-2015 sustainable development agenda, and formulation of national policies in the context of existing regional trade agreements. Trade and Development Commission, Geneva.

Wackernagel, M., \& Yount, J. D. (1998). The ecological footprint: an indicator of progress toward regional sustainability. Environmental Monitoring and Assessment, 51(1-2), 511-529.

WECD (1987). Our Common Future. Retrieved from: http://www.un-documents.net/our-common-future.pdf

Zilahy, G., \& Huisingh, D. (2009). The roles of academia in regional sustainability initiatives. Journal of Cleaner Production, 17(12), 1057-1066. 